\title{
UNSUR KEMODERENAN \\ DALAM MAZHAB INBU HANBAL
}

\author{
H. M. Mawardi Djalaluddin
}

Fakultas Syariah dan Hukum Universitas Islam Negeri (UIN) Alauddin Makassar

\begin{abstract}
The Hanbali school is the fourth school in the history of Islamic schools of Islamic jurisprudence recognized among Muslims. Hanbali Hanbali modernity is the new ideas of Imam Ahmad bin Hanbal and Hanbali Hanbali figures who came later and develop rationally Hanbali School that has many followers in the Islamic world.
\end{abstract}

\section{Keywords:}

Modernization, Madhhab of Ibn Hanbal

\begin{abstract}
Abstrak
Mazhab Hanbali merupakan mazhab keempat dalam sejarah perkembanagan mazhab dalam fiqh Islam yang diakui di kalangan umat Islam. Wujud kemodernan Mazhab Hanbali adalah adalah pemikiran-pemikiran baru dari Imam Ahmad bin Hanbal dan tokohtokoh Mazhab Hanbali yang datang kemudian dan mengembangkan secara rasional Mazhab Hanbali sehingga memiliki banyak pengikut di kawasan dunia Islam.
\end{abstract}

Kata Kunci:

Modernisasi, Mazhab Ibnu Hanbal

\section{A. PENDAHULUAN}

\section{Latar Belakang Masalah}

emoderenan atau modernisme, modernisasi dan modernitas merupakan
padanan kata dari pembaharuan. Modernisasi lahir di Dunia Barat, yang
muncul sejak renaisans terkait dengan masalah agama. Menurut masyarakat Barat kata modernisasi itu mengandung pengetian pikiran, ide, aliran, gerakan dan usahan untuk mengubah paham-paham, ada istiadat, dan sebagainnya agar semua itu dapat disesuaikan dengan perkembangan zaman yang ditimbulkan oleh kemajuan ilmu pengetahuan dan teknologi. ${ }^{1}$

Modern berarti terbaru, mutakhir atau sikap dan pola pikir serta tindakan yang sesuai dengan tuntutan zaman. Sedangkan modernisasi adalah suatu proses pergeseran sikap dan mentalitas sebagai warga masyarakat untuk dapat hidup

\footnotetext{
${ }^{1}$ Yusran Asmuni, Pengantar Studi Pemikiran dan Gerakan Pembaharuan Dalam Dunia Islam, 2.
} 
sesuai dengan tuntutan hidup masa kini. Modernisasi atau pembaharuan disebut juga dengan "reformasi", yakni membentuk kembali, atau mengadakan perubahan atau perbaikan kepada yang lebih baik. Dalam bahasa Arab, modernisasi atau pembaharuan sering diartikan dengan tajdid (yang memperbaharui), sedangkan pelakunya disebut mujaddid (orang yang melakukan pembaharuan). ${ }^{2}$

Modernisasi dilakukan dengan melakukan penemuan mutakhir oleh manusia di bidang ilmu pengetahuan. Dan pengetahuan itu sendiri merupakan hasil pemahaman manusia terhadap hukum-hukum yang obyektif yang menguasai alam, ideal dan material, sehingga alam ini berjalan sesuai dengan kepastian tertentu dan harmonis. Manusia yang bertindak menurut ilmu pengetahuan (ilmiah), ialah manusia yang bertindak menurut hukum alam yang berlaku. ${ }^{3}$ Jadi modernisasi itu adalah rasionalisasi yang ditopang oleh dimensi-dimensi moral, dengan berpijak pada prinsip iman kepada Tuhan Yang Maha Esa.

Unsur-unsur kemodernan dalam fiqh Islam sesungguhnya sudah ada pada setiap masa dalam perkembangan masyarakat Islam. Demikian pula dengan unsureunsur kemodernan dalam mazhab termasuk Mazhab Hanbali, yakni munculnya gerakan pembaharuan pemikiran yang berbeda dari seorang tokoh seperti Ahmad bin Hmbal termasuk para pengikutnya. Karena itu, kajian dalam makalah ini menekankan pada unsur kemodernan pemikiran mazhab Hanbali yang berorientasi pada pemiiran tokoh-tokoh mazhab tersebut.

\section{Rumusan Masalah}

Berdasarkan factor-faktor yang telah dikemukan di atas, maka uraian selanjutnya adalah terkait dengan permasalahan di bahwa ini.

1. Bagaimana Pengertian Unsur-Unsur kemoderenan?

2. Bagaimana Prototipe Mazhab Hanbali?

3. Bagaimana Wujud Kemoderenan dalam Mazhab Hanbali?

\section{B. PEMBAHASAN}

\section{Pengertian Unsur-Unsur Kemoderenan}

Berkenaan dengan pengertian unsur-unsur modern, para ahli berbeda-beda dalam memberikan tanggapan. Ada yang menekankan bahwa unsur-unsur kemodernan itu adalah rasional. Sebaliknya, yang selalu mengetengahkan emosi tidak disebut modern. Ahli lain melihat bahwa unsur-unsur kemodernan itu sama dengan kemajuan yakni orang-orang yang selalu menghargai perubahan karena perubahan tersebut merupakan sunnatullah. Ada juga yang mengatakan bahwa unsur-unsur kemodernan itu adalah sesuatu yang baru muncul atau sesuatu yang bersifat kontemporer sebagai lawan dari klasik. Karena itu, kata kemodernan selalu terkait dengan modernisasi yang menurut Nucholish Madjid pengertiannya identik

\footnotetext{
${ }^{2}$ Nurcholish Madjid, Islam Kemoderenan dan Keindonesiaan (Cet. I; Bandung: Mizan, 1987, 172.

${ }^{3}$ Nurcholish Madjid, Islam Kemoderenan dan Keindonesiaan, h. 172.
} 
dengan pengertian rasionalisasi atau proses perombakan pola berpikir dari tata kerja lama yang tidak rasional dan menggantinya dengan tata kerja rasional dengan tujuan untuk memperoleh daya guna dan efisiensi yang maksimal. ${ }^{4}$

Membicarakan kemoderenan secara umum tidak dapat dilepaskan dari aspek psikologis karena ia banyak terkait dengan nilai, sikap dan prilaku seseoarang secara individu. Begitupula dengan membicarakan paham mazhab Islam modern dalam Islam tidak dapat dilepaskan dari pembicaran paham mazhab Islam tradisional bahkan paham post modernisme karena Islam modern dicirikan dengan pendekatan rasional ilmiah sementara paham tradisional dicirikan dengan keterkaitan lebih berat dengan tradisi-tradisi yang didukung leh emsi dan rasa sedangkan post modernism dicirikan dengan upayanya dalam menitikberatkan penghargaan terhadap perbedaan-perbedaan dan tidak terkungkung dengan tradisi dan lebih menyatukan antara sisi rasio dan emosi. ${ }^{5}$

Ada yang mengaitkan istilah kemoderenan dengan pemikiran Barat sebagaimana dinyatakatan oleh Sigit Bayu Aji bahwa pemikiran kontemporer Islam yuang bersifat islami itu dihubungkan dengan kemodernan yang identik dengan Barat. Oleh karena pemikiran merupakan wacana yang berkembang secara dialektik, yakni dalam periodesasi waktu atau tempat atau kawasan tertentu, sehingga kita dapat memahami arti modern dan islami. Karena itu, dalam wacana pemikiran modern antara Islam dan Barat titik utama kajiannya terletak pada tataran epistemologis yakni sumber pengetahuan. Corak pemikiran Islam sesuai dengan sumber pengetahuannya yang selalu mengacu pada Alquran dan sunnah, maka dari itu segala bentuk kajian yang menafikan Alquran dan sunnah tidak dapat dikatakan sebagai pemikiran Islam. Sekalipun dari segi aksiologis akan berbeda bahwa pemikiran Barat dan Islam akan mengalami bias dan hilang corak kekhasannya karena disesuaikan dengan realitas yang ada. Islam tidak menantang upaya rasional hanya saja bahkan Islam menganjurkan penggunaan rasio untuk memahami syariat di sini rasio perlu didukung oleh upaya lain yaitu untuk menemukan kebenaran ilmiah. ${ }^{6}$.

\section{Prototipe Mazhab Hanbali}

Nama lengkap dari pendiri Mazhab Hanbali adalah Ahmad bin Muhammad bin Hanbal al-Syaibani al-Marzawi. Beliau dilahirkan di Marwa pada tahun 164 H/778 M dan wafat pada tahun 241 H.855 M di Baghdad, Iraq. Ahmad bin Hanbal merupakan keturunan Arab dan secara silsilah nasabnya sampai kepada Nabi Muhammad Saw. Ayahnya meninggal ketika Ahmad masih kecil kemudian ia

\footnotetext{
${ }^{4}$ Nurcholish Madjid, Islam Kemoderenan dan Keindonesiaan, h. 172.

${ }^{5}$ Noeng Muhajir, Filsafat Ilmu Positivisme, Post Positivisme dan Post Modernisme (Cet. I; Yogyakarta: Rake Sarasin, 2001), h. 206.

${ }^{6}$ Kebenaran ilmiah bukan kebenaran rasio semata karena ontologik apalagi paradigm filsafat ilmu dalam Islam memaparkan empiric sensual, empiric logic, empiric etik dan emprik transedental. Noeng Muhajhi, Suplemen Filsafat Ilmu Edisi II; Filsafat Islam Telaah Fungsional (Cet. I; Yogyakarta: Rake Sarasen, 2003), h.3.
} 
diasuh oleh ibunya, ayahnya termasuk tokoh pejuang dan kakeknya yang bernama Hanbal bin Hilal pernah menjabat sebagai gubernur di daerah Sarkhas salah satu daerah kekuasaan Pemerintahan Bani Umayyah tetapi ia bersimpati kepada golongan Abbasiyun bahkan menjadi juru dakwah mereka yang paling terkemuka. Daerah Sarkhas merupakan pusat gerakan orang-orang yang membela golongan Abbasiyun hingga runtuhnya daulah Umayyah. ${ }^{7}$

Ahmad bin Hanbal menghafal Alquran pada usia relatif muda, ia belajar hadis, bahasa, dan masalah-masalah administrasi. Ia banyak menimba ilmu dari sejumlah ulama dan fuqaha besar, salah satunya adalah Abu Yusuf (w. 182 H), seorang hakim dan murid Abu Hanifah. Dari Abu Yusuf ia mendapat pelajaran fiqh ahlu ra'yu. Setelah beberapa lama mempelajari fiqh ahlu ra'yu ia beralih ke kajian sunnah dan hadis yang semula dipelajarinya dari Hisyam bin Basyir ibn Abi Khazim seorang tokoh ahlu hadis di Baghdad. Selama empat tahun ia mempelajari hadis dari gurunya dengan memperoleh pengetahuan hadis yang sangat luas dan menulis sekitar 300.000 hadis. Selanjutnya, ia mempelajari hadis pada Imam al-Syafi'i, khususnya dalam bidang perumusan dan teknik pengambilan hukum. ${ }^{8}$

Untuk memperdalam ilmunya, ia mengembara ke berbagai wilayah seperti Kufah, Basra, Madinah, Makkah dan Yaman. Di Makkah Ahmad bin Hanbal mendalami ilmu fiqh dan usul fiqh kepada Imam al-Syafi'i. Pada usia 40 tahun ia kembali ke kampung halamannya dengan membawa seperangkat ilmu dan telah mencapai derajat mujtahid karena secara otoritatif ia layak melakukan ijtihad secara mandiri dan di sinilah ia kemudian dikenal dengan mazhab Hanbali. ${ }^{9}$ Sumber lain menyebutkan bahwa suatu ketika ada orang yang menegurnya, Ya Abdullah (Julukan Ahmad bin Hanbal), anda sudah sampai pada tingkat mujtahid dan anda sudah pantas menjadi imam kaum muslimin, apakah anda akan membawa tempat tinta ke kuburan, Ahmad menjawab dengan tenang, saya akan menuntut ilmu sampai saya masuk ke liang lahat. ${ }^{10}$

Mengacu pada uraian di atas, maka dipahami bahwa Ahmad bin Hanbal sangat antusias dalam mencari ilmu dan keterlibatannya dalam berbagai kajian keilmuan pada zamannya menempatkan ia sebagai salah seorang ahli fatwa yang sangat disengani dan diminati oleh umat Islam, sehingga ia dikenal juga sebagai tokoh yang sangat mencintai pemikiran-pemikiran pendahulunya, seperti Imam alSyafi'i bahkan ia mengatakan bahwa hanya al-Syafi'ilah yang pantas memberikan fatwa pada zamannya. Kekagumannya pada al-Syafi'i sedikit banyak mempengaruhi cara berpikirnya dalam melakukan ijtihad. Hal ini juga menjadi bukti bahwa ia memiliki perhatian yang besar terhadap persoalan-persoalan fiqh. ${ }^{11}$

\footnotetext{
${ }^{7}$ Dedi Ismatullah, Sejarah Sosial Hukum Islam (Cet. I; Bandung: Pustaka Setia, 2011), h. 312.

${ }^{8}$ Abu Zahrah, Tarikh al-Mazahib al-Islamiyyah (Mesir: Dar al-Fikr al-Arabi, tt), h. 201.

${ }^{9}$ Dr. H. Roibin, M.HI, Dimensi-Dimensi Sosio-Antropologis Penetapan Hukum Islam dalam Lintasan Sejarah (Cet. I; Malang: UIN Maliki Press, 2010), h. 81.

${ }^{10}$ Ahmad Kholik, Melacak Sejarah Metodologi Ijtihad(Bandung: Shahifah, 2009), h. 230.

${ }^{11}$ Dedi Ismatullah, Sejarah Sosial Hukum Islam, h. 314.
} 
Imam Ahmad bin Hanbal meninggal setelah menderita sakit selama sembilan hari dengan meninggalkan berbagai karya tulis antara lain; Kitab al-Musnad sebuah karya yang menakjubkan karena kitab ini memuat lebih dari dua puluh tujuh ribu hadis. Kitab al-Tafsir, namun al-Zahabi mengatakan bahwa kitab ini telah hilang. Kitab al-nasikh wa al-mansukh. Kitab al-tarikh, Kitab hadis Syu'bah. Kitab Muqaddam wa Muakhhar fi al-Quran. Kitab Jawaban al-Quran. Kitab Manasik al-Kabir dan Kitab Manasik as-Shagir, dan masih banyak kitab lainnya. Dibandingkan dengan mazhab fiqh lainnya, perkembangan pengikut mazhab Hanbali agar tersendat hal ini disebabkan karena rata-rata ulama Mazhab Hanbali enggan duduk dalam pemerintahan seperti menempati jabatan qadi atau mufti, sehingga Mazhab Hanbali tidak pernah menjadi mazhab resmi negara.

Mengenai penulisan mazhab Hanbali tidak ditulis langsung oleh Imam Ahmad bin Hanbal bahkan ia tidak suka jika ada yang menulis pendapat dan fatwanya kalaupun ada hanya berupa catatan kecil khusus untuknya yang memuat beberapa masalah fiqh. Karena itu, kalangan yang berjasa menuliskan mazhab Imam Hanbal adalah murid-muridnya. Merekalah yang mengumpulkan pendapat dan fatwa sang imam lalu menyusunnya sesuai dengan urutan bab fiqh. Adapun orang pertama yang menyebarkan Mazhab Imam Hanbali adalah putranya yang bernama Shalih bin Ahmad bin Hanbal (w.290 H). Beliaulah yang menyebabkan mazhab ayahnya dengan cara mengirimkan surat kepada orang yang bertanya dengan jawaban yang pernah disampaikan oleh ayahnya. Putra Imam Ahmad bin Hanbal yang lain yang bernama Abdullah bin Ahmad (w. $266 \mathrm{H}$ ) juga melakukan hal yang sama dengan mengumpukan kitab al-Musnad dan menyusunnya serta menukilkannya fiqh sang ayah. Murid Ima Ahmad bin Hanbal yang giat menulis mazhab dan menyebarkannya antara lain Abu Bakr al-Asy"ram, Abdul Malik al-Maimun dan Abu Bakr al-Mawaruzi serta Umar bin Ali bin Husain al-Hazmi (w. 234 H) yang menulis Kitab Monumental al-Mukhtasar al-Khiraqi yang lebih lanjut disyarahi oleh Ibnu Qudamah menjadi kitab al-Mughni. Setelah mereka datanglah dua imam besar yang mengklasifikasikan diri pada mazhab Imam Hanbali, yaitu Ahmad Taqiyuddin ibnu Taimiyyah (w.728 H) dan Ibnu Qayyim al-Jauziyyah (w.751 H).Keduanya dikenal sebagai orang yang menisbatkan diri pada Mazhab Hanbali. ${ }^{12}$

Berkat jasa kedua murid Imam Ahmad bin Hanbal inilah, sehingga pada Abad XII Mazhab Hanbali berkembang pesat terutama pada masa pemerintahan Raja Abdul Aziz al-Su'ud dan dianut oleh kebanyakan penduduk Hijaz, di pedalaman Oman dan beberapa tempat sepanjang Teluk Persia dan beberapa kota di Asia Tengah dan masa sekarang ini menjadi mazhab resmi di seluruh Jazirah Arab, Palestina, Siria dan Irak. ${ }^{13}$

\footnotetext{
${ }^{12}$ Rasyad Hasan Khalil, Sejarah Legislasi Hukum Islam (Jakarta: Amzah, 2009), h. 197.

${ }^{13}$ Rasyad Hasan Khalil, Sejarah Legislasi Hukum Islam, h. 197.
} 


\section{Wujud Kemodernan dalam Mazhab Hanbali}

Berdasarkan periodesasinya, Imam Hanbali menempati urutan keempat setelah Imam al-Syafi'i. Mazhab ini dianggap sangat rigit di dalam berpegang kepada hadis nabi, sehingga mazhab ini dikenal dengan fikhu al-sunnah. Selain itu, mazhab ini dikenal juga karena sangat ketat dalam berpegang terhadap fatwa sahabat. ${ }^{14}$ Besarnya pengaruh pemikiran ijtihad sahabat terhadap Ahmad bin Hanbal dapat dilihat dari dua aspek, yaitu metode istinbath dan dalil hukum yang digunakannya di mana agak berbeda dengan pendahulunya, baik Imam Malik maupun Imam alSyafi'i. Ahmad bin Hanbal tidak begitu banyak dipengaruhi keduanya dalam melakukan istinbat hukum terutama dalam mengambil sumber rujukannya terhadap mazhab sahabat. ${ }^{15}$

Dalam banyak hal, pemikiran fiqh Ahmad bin Hanbal merujuk pada pada fatwa sahabat tanpa membedakan apakah fatwa itu mempunyai dasar dari sunnah atau atsar atau sekedar diperoleh dari ijtihad mereka. Sekalipun demikian tidak dapat dikatakan bahwa Ahmad bin Hanbal telah menghidupkan fatwa-fatwa sahabat tanpa verifikasi ilmiah yang memadai tetapi ia menganggap fatwa-fatwa itu sebagai rujukan kedua setelah hadis dalam memahami agama dan hukum syara adalah satu kenyataan yang sulit dibantah. Dengan mengamati hal tersebut, maka dapat diasumsikan bahwa keteguhan Ahmad bin Hanbal dalam mengedapankan fatwa-fatwa sahabat sebagai rujukan dalam istinbat hukumnya cukup menjadi indikator bahwa dari jalur inilah pemikiran fiqh sahabat membentuk pemikiran fiqh Ahmad bin Hanbal. ${ }^{16}$

Mengacu pada uraian di atas, maka tidak mudah memetakan arah aliran pemikiran fiqh Ahmad bin Hanbal. Jika ditarik pada masa sahabat, apakah jalur ahlu hadis dari jalur Ibnu Abbas atau ahlu ra'yu dari jalur Umar bin al-Khattab akan tetapi indikator itu bisa dipetakan dengan penggunaan qiyas oleh Ahmad bin Hanbal sebagaimana dikatakan oleh Ibnu Qayyim bahwa Ahmad bin Hanbal tidak pernah menggunakan qiyas kecuali dalam keadaan sangat darurat. Dengan demikian, penggunaan qiyas yang pernah dilakukan oleh gurunya tidak banyak berpengaruh pada Ahmad bin Hanbal bahkan sikap dan pemikirian fiqh Ahmad bin Hanbal yang cenderung fundamentalistik dalam memegang hadis sebagaimana dilakukan sebagian besar sahabat telah menjadi potensi dasar bagi upayanya untuk melakukan perombakan pemahaman agama yang dianggap telah mengalami distorsi oleh kepentingan politik dan aliran pada zamannya menuju pemahaman komprehensif para sahabat. ${ }^{17}$

${ }^{14}$ Dr. H. Roibin, M.HI, Dimensi-Dimensi Sosio-Antropologis Penetapan Hukum Islam dalam Lintasan Sejarah, h. 81.

${ }^{15}$ Dedi Ismatullah, Sejarah Sosial Hukum Islam, h. 314.

${ }^{16}$ Ahmad Kholik, Melacak Sejarah Metodologi Ijtihad, h. 232-233.

${ }^{17}$ Dedi Ismatullah, Sejarah Sosial Hukum Islam, h. 315. 
Argumentasi di atas dipertegas oleh Ibnu Qayyim bahwa pandangan dan pemikiran-pemikiran fiqh Ahmad bin Hanbal berbeda dengan fatwa-fatwa sahabat. Bagi Ahmad bin Hanbal, fatwa sahabat merupakan satu-satunya penerang yang menyelesaikan problema pemikiran pada zamannya. Indikator lain yang bisa dijadikan dasar adalah bahwa sebagian besar fiqh Ahmad bin Hanbal merupakan pemikiran dan fatwa sahabat adalah upayanya dalam merujuk sumber hukum yang sering tidak membandingkan fatwa-fatwa sahabat dan hadis-hadis yang diriwayatkan para sahabat apakah lemah atau sahih. Baginya, apa yang dilakukan sahabat lebih banyak memiliki pesan sahih. ${ }^{18}$

Konsistensinya yang begitu kuat terhadap fiqh sahabat juga dapat dilihat dalam menempatkan urutan sumber hukum ketika melakukan istinbath seperti yang dinyatakan oleh Salim Ali al-Saqafi bawa Ahmad bin Hanbal dan para pengikutnya sangat konsisten menempatkan fatwa dan fiqh para sahabat sebagai sumber hukum setelah menggunakan nushusus syariat dari sepuluh dasar istinbath yang dilakukan oleh Ahmad bin Hanbal dan pengikutnya, ia menempatkan fiqh sahabat sebagai dasar yang kedua. ${ }^{19}$

Kenyataan di atas menegaskan bahwa pemikiran fiqh sahabat pada masa awal mempengaruhi sistem ijtihad yang dibangun oleh Ahmad bin Hanbal. Sebagain literatur menyebutkan bahwa di samping sangat konsisten dalam penggunaan fatwa sahabat, Ahmad bin Hanbal juga dikenal sebagain orang yang keras pemikirannya pada zamannya karena ia dikenal sebagai pembela hadis. Hal ini dapat dilihat dari cara-caranya dalam memutuskan hukum, ia tidak suka menggunakan akal kecuali dalam keadaan yang sangat darurat dan terpaksa serta sebatas tidak ditemukan hadis yang menjelaskannya. Keteguhannya dalam menggunakan hadis sampai pada penggunaan hadis mursal dan hadis dhaif. Bagi Ahmad bin Hanbal, penggunaan hadis mursal dan hadis dhaif lebih selamat dari pada menggunakan akal dan qiyas. Penggunaan hadis mursal dan dhaif ia tempuh setelah tidak dijumpai ada hadis lain yang setingkat, ${ }^{20}$ atau tidak ada pendapat sahabat dan tidak ada pula kesepakatan sahabat yang menentangnya. Karena konsistensinya yang begitu kuat dalam mempertahankan hadis sebagai hujjah dan sistem ijtihadnya, Ahmad bin Hanbal dapat dikategorikan sebagai ahlu fiqh yang cenderung beraliran ahlu hadis yang jika dihubungkan dengan jalur sebelumnya, maka ia akan sampai kepada jalur Imam Malik dan aliran ahli hadis di kalangan sahabat. ${ }^{21}$

Mengacu pada uraian di atas dapat dipahami bahwa unsur-unsur kemodernan dalam pemikiran Imam Hanbal adalah keberaniannya dalam membedakan dan membangun pendapat fiqhnya sendiri dan membentuk pondasi pemikiran baru

\footnotetext{
${ }^{18}$ Dedi Ismatullah, Sejarah Sosial Hukum Islam, h. 315.

${ }^{19}$ Salim Ali Ash-Tsaqafi, Mafatih al-Fiqh al-Hambali (Mekkah: tp, tt), h. 361-391.

${ }^{20}$ Yang diaksud hadis dhaif oleh Ahmad bin Hambal adalah hadis yang tidak mengandung unsur bathil atau munkar atau yang di dalamnya tidak terdapat perawi yang muttaham. Baginya, hadis dhaif termasuk kategori hadis yang sahih atau hasan. Lihat Dedi Ismatullah, Sejarah Sosial Hukum Islam, h. 316.

${ }^{21}$ Dedi Ismatullah, Sejarah Sosial Hukum Islam, h. 316.
} 
yang tidak dipengaruhi oleh pemikiran gurunya (Imam al-Syafi'i). Unsur lain dari kemodernannya adalah pernyataan-pernyataan tentang dialektika pemikiran yaitu Unsur pemikiran moderat Ahmad bin Hanbal dapat dilihat dari beberapa pernyataannya tentang dialektika pengetahuan dan toleransi berpikir. Ia menyatakan bahwa janganlah kamu mengikuti aku dan jangan pula engkau mengikuti Malik, al-Syafi'i, al-Auza'i dan al-Tsauri tetapi ambillah dari mana mereka mengambil. Pendapat Auza'i, pendapat Malik dan pendapat Abu Hanifah semuanya adalah pendapat dan ia bagiku adalah sama, sedangkan alasan hanyalah terdapat di dalam atsar-atsar. Barang siapa yang menolak hadis Rasululah, sesungguhnya ia telah berada di tepi kehancuran.

Selanjutnya, unsur kemodernan Mazhab Hanbali semakin dipertegas oleh pemikiran dua tokoh terkenal dalam sejarah fiqh Islam, yaitu Ibnu Taimiyyah ${ }^{22}$ dan Ibnu Qayyim al-Jauzi. ${ }^{23}$ Ide-ide pembaharuan Ibn Taimiyah terfokus pada masalah fiqh dan teologi di mana ia menemukan kesalahan sebagian umat Islam dalam melakukan interpretasi terhadap fiqh atau hukum Islam sehingga yang benar menjadi salah dan begitu juga sebaliknya. Selain itu ia juga melihat bahwa perkembangan Islam di berbagai bidang, terutama fiqh, teologi, politik dan tasawuf mengalami ketidaktentuan sehingga tidak terkontrol dan berkembanglah neo-fiqh, neo-kalam, dll. ${ }^{24}$ Karena itulah menurut Ibn Taimiyah, sebagaimana dikutip oleh Fazlurrahman, diperlukan suatu langkah untuk kembali kepada Alquran dan hadis karena banyak dari kebenaran telah ditinggalkan sedangkan kesalahan banyak diambil sehingga kebenaran dan kesalahan tercampur. ${ }^{25}$ Selain itu juga diperlukan ijtihad karena para ahli fiqh tidak lagi melakukan karya ilmiyah setelah adanya

${ }^{22}$ Ibn Taimiyah lahir di Harran pada tahun 1263 M. lima tahun setelah kehancuran Baghdad dalam agama dan intelektual yang sangat kuat di Syria. Ayahnya, Syihabuddin, adalah Ahli ilmu Hadis terkenal dan Khatib di Masjid Agung di Damaskus, sedangkan pamannya, Fakhruddin adalah cendikiawan dan penulis terkenal. Pada tahun 1269 ia bersama keluarganya terpaksa mengungsi ke Damaskus karena serbuan tentara Mongol yang hendak menguasai Syria Selatan. Ibnul Qayyim (691-751 H/ 1292-1350 M) Shams aI-Din Abu 'Abdullah Muhammad Ibn Abu Bakr, dikenal dengan nama besar Ibn Qayyim al-Jawziyyah, lahir diDamaskus, 7 Safar 691 H (29 Januari, 1292 M) dan meninggal pada 23Rajab 751 H (26 September, 1350 M). Murid Ibnu Taimiyyah. Hidup di masa Sultan NasirMuhammad bin Qalawun (1293-1341 M). Kondisi sosial ekonomi danpolitik yang meliputinya memang cukup kondusif dan stabil. Khalifahsaat itu sangat peduli dengan perkembangan ilmu pengetahuan danpendidikan. Ulama memiliki peran penting dan berpengaruh kepadakhalifah dan rakyat saat itu. Khalifah saat itu melakukan redistribusikepemilikan tanah dan reformasi perpajakan. Qamaruddin Khan, Pemikiran Politik Ibn Taimiyah (Cet. I; Penerbit PUSTAKA, 1903), h. 11.

${ }^{23}$ Ibnul Qayyim (691-751 H/ 1292-1350 M) Shams al-Din Abu 'Abdullah Muhammad Ibn Abu Bakr, dikenal dengan nama besar Ibn Qayyim al-Jawziyyah, lahir diDamaskus, 7 Safar 691 H (29 Januari, 1292 M) dan meninggal pada 23Rajab 751 H (26 September, 1350 M). Murid Ibnu Taimiyyah. Hidup di masa Sultan NasirMuhammad bin Qalawun (1293-1341 M). Kondisi sosial ekonomi danpolitik yang meliputinya memang cukup kondusif dan stabil. Khalifahsaat itu sangat peduli dengan perkembangan ilmu pengetahuan danpendidikan. Ulama memiliki peran penting dan berpengaruh kepadakhalifah dan rakyat saat itu. Khalifah saat itumelakukan redistribusikepemilikan tanah dan reformasi perpajakan.

${ }^{24}$ Fazlurrahman, Gelombang Perubahan Dalam Islam: Studi Tentang Fundamentalisme Islam (Cet. II; PT. Raja Grafindo Persada 2000), h. 186.

${ }^{25}$ Fazlurrahman, Gelombang Perubahan Dalam Islam: Studi Tentang Fundamentalisme Islam, h. 187. 
imam mazhab yang empat dan fiqh pun menjadi bentuk opini yang memburuk di tangan orang-orang yang setengah tahu. ${ }^{26}$

Karena fatwa-fatwanya yang dianggap radikal dalam memberantas khurafat, Ibn Taimiyah kurang disenangi yang menyebabkannya dijebloskan ke penjara. Ibn Taimiyah kembali ke Syira dan meneruskan ide-ide pembaharuaannya tersebut hingga meninggal pada $1328 \mathrm{M}$. Zainal Abidin Ahmad menyebutkan bahwa Ibn Taimiyah selama 16 tahun hingga wafatnya pekerjaannya adalah keluar masuk penjara. ${ }^{27}$

Sementara Ibnu Qayyim al-Jauzi menjelaskan metodologi pembaharuan pemkiran Hanbali dengan menyatakan bahwa mazhab Hanbali dibangun di atas lima pilar, yaitu;

1. Alquran dan sunnah. Jika ia menemukan nas ia akan menggunakannya dalam berfatwa dan tidak menggunakan yang lain, tidak mendahulukan pendapat sahabat daripada hadis shahih atau amalaln penduduk Madinah atau lainnya tidak pula logika, kiyas atau ketidaktahuan adanya nas yang menentangnya yaitu apa yang dinamakan ijma.

2. Fatwa Sahabat. Imam Ahmad bin Hanbal menjadikan fatwa sahabat sebagai standar hukum nomor tiga setelah Alquran dan sunnah karena menurutnya fatwa sahabat diambil dari hadis shahih. Dalam hal ini ulama yang banyak mengeluarkan fatwa adalah Umar bi al-Khattab, Ali bin Abi Thalib, Abdullah bin Abi Mas'ud, Abbbdullah bin Abbas, Zaid bin Tsabit, Sayyidah Aisyah serta Abu Bakr, Usman bin Affan, Muaz bin Jabal, Sa'ad bin Abi Waqqas, Thalhah bin ABi Ubaidillah, Zubair bin Awwam, Abdullah bin Umar dan Salman al-Farisi adalah sahabat yang tidak terlalu banyak mengeluarkan fatwa. ${ }^{28}$

3. Qiyas. Jika tidak ada nas dari Alquran dan sunnah atau pendapat sahabat atau hadis mursal atau hadis dhaif maka beliau baru mengambil kiyas tetapi dalam hal ini Imam Hanbali hanya mengambil kiyas yang berasal dari ulama terdahulu. Selain itu, beliau juga menggunakan hadis mursal dan hadus dhaif jika tidak ada dalil yang menguatkannya dan didahulukan daripada kiyas. Hadis mursal, hadis dhaif. Adapun hadis dhaif menurut Imam Hanbal bukanlah hadis batil atau munkar atau perawinya yang diutuduh dusta serta tidak boleh diambil hadisnya namun yang beliau maksud dengan kandungan hadis dhaif adaah orang yang belum mencapai derajat siqah tetapi tidak sampai dituduh berdusta dan jika memang demikian maka iapun bagian dari hadis shahih. ${ }^{29}$

4. Istishab. Yaitu melangsungkan keberlakuan ketentuan hukum yang ada sehingga terdapat ketentuan dalil yang mengubahnya. Istishab yang dimaksud

${ }^{26}$ Fazlurrahman, Gelombang Perubahan Dalam Islam: Studi Tentang Fundamentalisme Islam, h. 192193.

${ }^{27}$ Zainal Abidin Ahmad, Sejarah Islam dan Umatnya: Perkembangannya Dari Zaman ke Zaman, Bulan Bintang, Cet. ke 1, 1979, h.245.

${ }^{28}$ Ahmad Kholik, Melacak Sejarah Metodologi Ijtihad, h. 224.

${ }^{29}$ Dr. Mustofa as-Saq'ah, Imam Ahmad bin Hanbal. Juz 4 (Beirut: Dar al-Kitab, 1998), h. 220. 
baik berupa istishab akli (melangsungkan keberlakuan hukum akal menegani kebolehan atau bebas asal pada saat tidak dijumpai dalil yang mengubahnya) dan istishab syar'I (melangsungkan keberlakuan hukum syara berdasarkan suatu dalil dan tidak ada dalil yang mengubahnya. ${ }^{30}$

5. Sad az-Zara'i. Maksudnya adalah menghambat dan menghalagi dan menyumbat segala hukum yang menuju kerusakan atau maksiat. Tujuan dari metode ini adalah menarik kemaslahatan dan menjauhi kerusakan. Pada awalnya perbuatan yang dimaksud tidak memiliki hukum tetapi apabila dibiarkan akan menjerumuskan manusia kedalam perbuatan dosa seperti permainan yang lazimnya berujung pada perjudian. ${ }^{31}$

Memperhatikan tempat-tempat pelaksanaan ibadah haji di Makkah dan sekitarnya, tempat tawaf-sai besusun, pelebaran-peluasan tempat bermalam di Mina adalah bukti nyata pembaharuan spektakuler dalam mazhab Hanbali. Pemerintah Arab Saudi mengambil mazhab Hanbali, sebagai mazhab resmi kerajaan-negara.

\section{PENUTUP}

\section{Kesimpulan}

Berdasarkan uraian di atas, maka kesimpulan dari makalah ini adalah sebagai berikut;

- Unsur kemodernan merupakan corak pemikran yang berbeda dengan pemikiran fiqh sebelumnya yang lahir sebagai sesutau yang baru.

- Mazhab Hanbali merupakan mazhab keempat dalam sejarah perkembanagan mazhab dalam fiqh Islam yang diakui di kalangan umat Islam.

- Wujud kemodernan Mazhab Hanbali adalah adalah pemikiran-pemikiran baru dari Imam Ahmad bin Hanbal dan tokoh-tokoh Mazhab Hanbali yang datang kemudian dan mengembangkan secara rasional Mazhab Hanbali sehingga memiliki banyak pengikut di kawasan dunia Islam.

\section{Implikasi Penelitian}

- Jadikanlah makalah ini sebagai pedoman yang bersifat untuk menambah wawasan pengetahuan, jadikan acuan pemahaman yang lebih dalam sebagai wadah untuk menampung ilmu.

- Makalah ini tentu jauh dari kesempurnaan, olehnya itu, siapa pun yang menemukan kesalahan penulisan atau kesalahan interpretasi, baik disengaja atau tidak, seyogyanya memperbaikinya, baik secara langsung maupun tidak, dengan melalui saran dan kritikan kepada penulis. Semoga makalah bisa berguna, minimal bagi penulis sendiri dan menjadi sebuah amal jariyah yang dicacat di sisi Allah Yang Maha Pemurah lagi Maha Pemaaf. Amin.

\footnotetext{
${ }^{30}$ Abdullah Mijib, Kawasan dan Wawasan Studi Islam (Cet. II; t.p, 2007), h. 201.

${ }^{31}$ Abdullah Mijib, Kawasan dan Wawasan Studi Islam, h. 202.
} 


\section{Daftar Pustaka}

Ahmad, Zainal Abidin. Sejarah Islam dan Umatnya: Perkembangannya Dari Zaman ke Zaman, Bulan Bintang, Cet. ke 1, 1979.

Ash-Tsaqafi, Salim Ali. Mafatih al-Figh al-Hanbali (Mekkah: tp, tt)

Asmuni, Yusran. Pengantar Studi Pemikiran dan Gerakan Pembaharuan Dalam Dunia Islam, 2

as-Saq'ah, Dr. Mustofa. Imam Ahmad bin Hanbal. Juz 4. Beirut: Dar al-Kitab, 1998.

Fazlurrahman, Gelombang Perubahan Dalam Islam: Studi Tentang Fundamentalisme Islam, PT. Raja Grafindo Persada, Cet. ke -1, Agustus 2000.

Ismatullah, Dedi. / Sejarah Sosial Hukum Islam. Cet. I; Bandung: Pustaka Setia, 2011.

Khalil, Rasyad Hasan Sejarah Legislasi Hukum Islam. Jakarta: Amzah, 2009.

Khan, Qamaruddin. Pemikiran Politik Ibn Taimiyah, Penerbit PUSTAKA, Cet. ke-1, 1903.

Kholik, Ahmad. Melacak Sejarah Metodologi Ijtihad. Bandung: Shahifah, 2009.

Madjid, Nurcholish. Islam Kemoderenan dan Keindonesiaan. Cet. I; Bandung: Mizan, 1987.

Mijib, Abdullah. Kawasan dan Wawasan Studi Islam. Cet. II; tp, 2007.

Muhajhi, Noeng. Suplemen Filsafat Ilmu Edisi II; Filsafat Islam Telaah Fungsional. Cet. I Yogyakarta: Rake Sarasen, 2003.

........, Filsafat Ilmu Positivisme, Post Positivisme dan Post Modernisme. Cet. I; Yogyakarta: Rake Sarasin, 2001.

Roibin, Dr. H. M.HI, Dimensi-Dimensi Sosio-Antropologis Penetapan Hukum Islam dalam Lintasan Sejarah. Cet. I; Malang: UIN Maliki Press, 2010.

Zahrah, Abu. Tarikh al-Mazahib al-Islamiyyah. Mesir: Dar al-Fikr al-Arabi, t.t. 